\title{
Ambulatory treatment of multibacillary leprosy with a regimen of 8 months duration
}

\author{
S R PATTYN, * J BOURLAND $\dagger \&$ KAZEZE $\dagger$ \\ *Laboratory of Leprosy, Institute of Tropical Medicine, Antwerp, \\ Belgium; †Service intégré lèpre-turberculose, Bujumbura, Républi- \\ que du Burundi
}

Accepted for publication 2 July 1991

\begin{abstract}
Summary An ambulatory treatment regimen for multibacillary leprosy, of 34 weeks duration composed of 8 weeks daily supervised rifampicin, ethionamide (ETH), dapsone (DDS) and clofazimine (CLO) followed by 26 weeks of unsupervised ETH, DDS and CLO, introduced in 1983 has been evaluated; 268 patients were followed for a mean of 4.4 years and a total of 1188 patient years. The relapse rate was 0.33 per 100 patient years of follow up. The reduction of the duration of the combined administration of RMP + ETH reduced the hepatotoxicity to $1.4 \%$. It is possible that both phases of the regimen studied could still be reduced, however in the near future ETH will be replaced by alternative bactericidal drugs, avoiding the hepatotoxicity.
\end{abstract}

\section{Introduction}

Previous work from our laboratory ${ }^{1-4}$ has shown that short course treatment, of less than 1 year's duration, is possible in multibacillary leprosy (MB) provided combined therapy with bactericidal drugs in sufficient dosage is administered. ${ }^{4}$ Until the end of the 1980s only 2 bactericidal drugs were available: rifampicin (RMP) and the thioamides, either ethionamide $(\mathrm{ETH})$ or prothionamide, but unfortunately their combined administration is hepatotoxic, ${ }^{5,6}$ even when the duration of their combined administration was reduced to 3 months. $^{4}$

Furthermore for the supervised daily administration of drugs in our previous studies, ${ }^{1-4}$ patients had to be hospitalized or to reside in the proximity of the treatment centre. This was not always possible in Burundi.

We therefore decided to study the efficacy and tolerance of an entirely ambulatory regimen consisting of two successive phases: a first period of 8 weeks of a daily supervised 4-drug regimen including RMP, ETH, DDS and CLO followed by a 6-month unsupervised triple drug regimen without RMP. 


\section{Patients and methods}

In the peripheral, rural health centre (HC), patients suspected of having leprosy were referred to the leprosy service personnel during their monthly visits, for clinical, neurological and bacteriological examinations and a skin biopsy to be fixed in $10 \%$ formalin. Slit-skin smears were taken-one from an earlobe and two from skin lesions. The biopsies together with a copy of the clinical file was sent to Antwerp, as was a copy of the treatment file when completed.

Patients were either newly diagnosed (new cases) or known cases who had been treated in the past with dapsone (DDS) monotherapy irregularly or had relapsed after DDS monotherapy had been stopped (old cases).

Patients able to visit the HC daily during the 8 weeks were included in the study and the necessary medication, in containers for daily delivery, was handed over to the responsible person in the $\mathrm{HC}$. Thereafter, during the second phase of treatment, medication sufficient for 4 weeks was delivered to the HC. All administrations of drugs were noted on an appropriate form. The treatment regimen was as follows:

8 weeks: RMP 600 mg, ETH 500 mg, DDS 100 mg, CLO 50 mg daily, 6 days a week, supervised in the $\mathrm{HC}$, followed by

26 weeks: ETH $500 \mathrm{mg}$, DDS $100 \mathrm{mg}$ and CLO $50 \mathrm{mg}$ daily 7 days a week, unsupervised, the drugs being collected from the HC once every 4 weeks.

In the present analysis only patients with a BI of 2 or more at any site, at the start of the study, are included. Treatment was considered complete if the first phase was completed within 9 weeks and the second within 30 weeks.

In the absence of any intercurrent complication follow-up examinations identical to those at intake were done yearly.

When relapse was suspected, clinical, bacteriological and histological examinations were repeated and if relapse was confirmed and also if feasible, a fresh skin biopsy, on ice, was sent to the laboratory in Antwerp for mouse footpad inoculation and drug sensitivity testing. For the latter RMP $10 \mathrm{mg} / \mathrm{k}$ was administered to mice once a week during 10 weeks by gastric gavage, DDS was mixed in the food at $10^{-2}, 10^{-3}, 10^{-4 \%}$, ETH at $10^{-2} \%$ and CLO at $3 \cdot 10^{-3}$.

\section{Results}

A total of 305 patients with a BI at the start of 2 or more at any site were taken into the trial: 146 new cases and 159 old cases. Six patients died before the end of the first year from causes unrelated to leprosy. Seventeen patients $(6 \cdot 2 \%)$ were lost during the first phase of treatment -1 because he left the country and 16 for unknown reasons. Fourteen patients $(4.5 \%)$ had to be excluded from the analysis because they failed to collect their last 1 or 2 monthly doses of drugs. Thus 268 patients were evaluated, 125 new cases and 143 old cases. They were followed for a mean of 4.4 years, and represent 1188 patient years of follow-up (Table 1). The mean BI at the start was 3.18 and declined with a mean of 0.53 per year. 
Table 1. Follow up and incidence of relapses in patients treated with the ambulatory regimen of $8+26$ weeks

\begin{tabular}{|c|c|c|c|c|c|c|}
\hline \multirow[b]{2}{*}{$\begin{array}{l}\text { Year of } \\
\text { follow-up }\end{array}$} & \multirow[b]{2}{*}{$\begin{array}{c}\text { Number of } \\
\text { patients seen }\end{array}$} & \multirow{2}{*}{$\begin{array}{l}\text { Person years of } \\
\text { follow-up } \\
\text { (cumulative) }\end{array}$} & \multicolumn{4}{|c|}{ Relapses } \\
\hline & & & Number & $\begin{array}{l}\text { Cumulative } \\
\text { number }\end{array}$ & $\begin{array}{c}\text { Incidence } \\
(\%)\end{array}$ & $95 \% \mathrm{CI}$ \\
\hline 1 & 268 & 268 & - & - & - & - \\
\hline 2 & 259 & 527 & - & - & - & - \\
\hline 3 & 242 & 769 & 1 & 1 & $0 \cdot 1$ & $0-0 \cdot 74$ \\
\hline 4 & 197 & 966 & 2 & 3 & $0 \cdot 3$ & $0.06-0.92$ \\
\hline 5 & 148 & 1114 & 1 & 4 & $0 \cdot 3$ & $0.06-0.87$ \\
\hline 6 & 68 & 1182 & - & 4 & $0 \cdot 3$ & $0 \cdot 06-0 \cdot 87$ \\
\hline 7 & 6 & 1188 & - & 4 & $0 \cdot 3$ & $0.06-0.87$ \\
\hline Mean 4.4 & & & & & & \\
\hline
\end{tabular}

CI, confidence interval.

Clinical evolution in all patients was very satisfactory. Four cases of hepatitis $(1 \cdot 4 \%)$ were diagnosed clinically at 7, 55, 68 and 208 days of treatment, with a mean of 84 days and a median of 61 days. None of them was fatal.

Four relapses, 3 in BL patients and 1 in a LL patient, have been diagnosed at respectively $31,41,43$ and 52 months after the end of treatment, with a mean and median of 42 months. One relapse was detected in a yearly follow-up biopsy, the other 3 cases were detected clinically.

Bacilli from 3 relapses were inoculated into mice, all were sensitive to the drugs administered to the patients.

Six cases of late reversal reactions were diagnosed at respectively 29, 30, 40, 41, 56 and 57 months after the end of treatment with a mean of 42 months and a median of $40 \cdot 5$ months. Five had been classified as BL and one as LL.

\section{Discussion}

The present study shows that MB leprosy can be cured by an ambulatory treatment of 8 months duration, composed of a daily supervised administration of 4 drugs, 2 of which, RMP and ETH are bactericidal, followed by 6 months of unsupervised administration of 3 drugs, one of which, ETH, is bactericidal.

The 48 doses of RMP administered during the first 8 weeks of treatment are supposed to kill all RMP sensitive organisms, while the 230 doses of ETH, DDS and CLO administered during the next 8 months should kill the remaining RMP-resistant organisms. ${ }^{5}$ The relapse rate of $0 \cdot 3 \%$ of the present $8+26$ weeks (w) regimen, compares favourably with the previously studied $13 \mathrm{w}$ regimen for which the relapse rate was $0 \cdot 28 \%$. It must be noted however that the follow-up for the $8+26 \mathrm{w}$ regimen of 4.4 years or 53 months is longer than for the 13 w regimen for which it was 3.5 years or 42 months. Compared with the $13 \mathrm{w}$ regimen, ${ }^{4}$ the $8+26 \mathrm{w}$ regimen implies the administration of greater quantities of drugs during a longer time period: 


\section{$8+26$ w RMP 48 doses within 8 weeks \\ ETH 230 doses within 34 weeks \\ DDS 230 doses within 34 weeks \\ CLO 230 doses within 34 weeks}

13w(4) RMP 26 doses within 13 weeks

ETH 78 doses within 13 weeks

DDS 78 doses within 13 weeks

CLO 78 doses within 13 weeks

Since both regimens have a comparable efficacy, the $8+26 \mathrm{w}$ regimen could probably be shortened. However the main advantage of the $8+26 \mathrm{w}$ regimen is the significant reduction of hepatotoxicity: $1 \cdot 4 \%$ instead of the $5 \%$ in previous studies ${ }^{6}(4 / 268$ versus $23 /$ $515, p=0 \cdot 05)$. This significant reduction was not observed with the $13 \mathrm{w}$ regimen: 14 cases among 439 patients. ${ }^{4}$ This most probably results from the reduced duration of the simultaneous administration of RMP + ETH during 8 weeks only. How much this could still be reduced in quantity or duration may now be an obsolete question since alternative drugs such as ofloxacine,${ }^{8}$ minocycline ${ }^{9}$ and macrolides may replace the use of ETH and probably avoid hepatotoxicity.

There is no evidence that the 14 patients who failed to collect their final one or two drug supplies did so because of hepatitis: they were also followed for 4-5 years and none of them developed a relapse. This supports the hypothesis and it may be possible to reduce the duration of the second phase in the present regimen, but the number of patients is too small to allow significant conclusions to be drawn.

As expected after treatment with a combined drug regimen, the strains isolated from the relapsing patients were sensitive to the drugs the patients had taken. This shows that in a small proportion of MB patients, some drug sensitive Mycobacterium leprae escape the action of the drugs and give rise to relapses, it is possible that a combination of more than 2 bactericidal drugs may solve this problem.

Once more the late reversal reactions, appearing in the present study af ter a mean of 42 months post-therapy should be differentiated from relapses on the basis of careful bacteriological and histopathological assessment.

In conclusion a treatment regimen of MB leprosy of 34 weeks duration, involving 8 weeks of daily supervised RMP, ETH, DDS and CLO followed by 26 weeks of unsupervised ETH, DDS and CLO gave most satisfactory results in terms of relapse rate while at the same time hepatotoxicity was reduced considerably.

\section{Acknowledgment}

This work was supported by the Damien Foundation, Brussels, and contract no. TS20027-B of the CEC.

\section{References}

1 Onsun N, Saylan T, Pattyn SR. Combined chemotherapy of multibacillary leprosy of 6 months duration. Le pr Rev, Suppl 3, 1986; 57: 124-6. 
2 Pattyn SR, Bourland J, Grillone S, Groenen G, Ghys P. Combined regimens of one year duration in the treatment of multibacillary leprosy. I. Combined regimen with rifampicin administered during one year. Lepr Rev, 60: 109-17.

3 Pattyn SR, Groenen G, Janssens L, Deverchin J, Ghys P. Combined regimens of one year duration in the treatment of multibacillary leprosy. II. Combined regimens with rifampicin administered during 6 months. Lepr Rev, 1989; 60: 118-23.

${ }^{4}$ Pattyn SR, Groenen G, Janssens L, Kuykens L, Mputu LB. Treatment of multibacillary leprosy with a regimen of 13 weeks duration. Lepr Rev, 1992; 63: 41-6.

5 Ellard GA. Chemotherapy of leprosy. Brit Med Bull, 1988; 44: 775-90.

${ }^{6}$ Pattyn SR, Janssens L, Bourland J, Saylan T, Davies E, Grillone S, Ferracci C. Hepatoxicity of the combination of rifampicin-ethionamide in the treatment of multibacillary leprosy. Int $J$ Lepr, 1984; 52: 1-6.

7 Cartel JL, Millan J, Guelpa-Lauras CC, Grosset JH. Hepatitis in leprosy patients treated by a daily combination of dapsone, rifampin and a thioamide. Int J Lepr, 1983; 51: 461-5.

${ }^{8}$ Grosset JH, Ji B, Guelpa-Lauras CC, Pevvani EG, N'Deli LN. Clinical trial of pefloxacin and ofloxacin in the treatment of lepromatous leprosy. Int J Lepr, 1990; 58: 281-95.

${ }^{9}$ Gelber RH. Activity of minocycline in Mycobacterium leprae infected mice. J Infect Dis, 1987; 186: $236-9$.

Lepr Rev (1992) 63, 36-40

\title{
Traitement ambulatoire de la lepre multibacillaire par un regime de 8 mois
}

\author{
S R Pattyn, J Bourland et Kazeze
}

Résumé Une évaluation a été faite du traitement ambulatoire de la lèpre multibacillaire au moyen d'un régime de 34 semaines dont 8 semaines d'un traitement supervisé journalier à la rifampicine, à l'éthionaide (EHT), à la dapsone (DDS) et à la clofazimine (CLO) suivi de 26 semaines d'un traitement non-supervisé de ETH, DDS et CLO introduit en 1983; 268 patients furent suivis pendant une moyenne de 4,4 ans et pendant un total de 1188 années-patients. La réduction de la durée de l'administration combinée de RMP+ETH avait réduit l'hépatotoxicité à $1,4 \%$. Il est possible que les deux phases du régime étudié puissent être encore réduites mais bientôt, ETH sera remplacé par d'autres bactéricides qui ne causent pas d'hépatotoxicité.

\section{El tratamiento ambulatorio de la lepra multibacilar con un regimen de duracion de 8 meses}

\author{
S R Pattyn, J Bourland y Kazeze
}

Resumen Se ha evaluado un regimen de tratamiento ambulatorio de la lepra multibacilar con una duración de 34 semanas, que consistía de 8 semanas de rifampicina, etionamida (ETH) dapsona (DDS) y clofazimina (CLO) con administración diaria vigilada, seguido por 26 semanas de ETH, DDS y CLO sin supervisión, fue introducido en 1983.

Se controlaron 268 pacientes por un promedio de 4,4 años y un total de 1188 pacientes-año. La tasa de recaída fue 0,33 por 100 pacientes-año de continuación de estudio. La reducción de la duración de la administración combinada de RMP + ETH, redujo la hepatotoxicidad, a 1,4\%. Es posible que se podría reducir ambas fases del regimen todavía más, pero en un futuro próximo se reemplazará la ETH con otras drogas bactericidas, para evitar la hepatotoxicidad. 